\title{
Effect of age, Helicobacter pylori infection, and gastritis with atrophy on serum gastrin and gastric acid secretion in healthy men
}

\author{
P H Katelaris, F Seow, B P C Lin, J Napoli, M C Ngu, D B Jones
}

\begin{abstract}
Gastric acid secretion has been considered to decline with increasing age but this view is being re-evaluated as the importance of Helicobacter pylori infection emerges. This study aimed to determine the effect of age, $H$ pylori, and gastritis with atrophy on the serum gastrin concentration, gastric secretory volumes, and acid output in healthy, asymptomatic men. Young men (mean (SD) age 22.9 $(0.6)$ years; $n=22$ ) were compared with old men $(72.9(1 \cdot 2)$ years; $n=28)$ in respect of basal serum gastrin and basal, sham fed, pentagastrin stimulated maximal and peak acid secretion. Antral, corpus, and fundal biopsy specimens were taken for histology and $H$ pylori status (histology, culture, and rapid urease test). $H$ pylori associated gastritis was present in three of 22 young $(13.6 \%)$ and 16 of 28 old $(57 \cdot 1 \%)$ men. Gastritis with atrophy was present in 11 old subjects, 10 of whom were $H$ pylori positive. These subjects had higher mean (SD) serum gastrin concentrations than old subjects without atrophy and young sub-
\end{abstract} jects (61.8 (9.2); 40.0 (2.9); 36.8 (2.3) pmol/l respectively; $\mathrm{p}<0.001)$. $H$ pylori infected subjects had higher gastrin values than uninfected subjects, overall (55.3 (5.9); 36.0 (1.8) pmol/l; $\mathrm{p}<0.001)$ and in subjects without atrophy (45.3 (4.2); 36.0 (1.8) $\mathrm{pmol} / \mathrm{l} ; \mathrm{p}<0.03)$. In subjects without $H$ pylori infection, gastrin values did not differ with age (old 37.1 (1.7); young 35.4 $(2 \cdot 1) \mathrm{pmol} / \mathrm{l})$. The maximal gastric secretory volume was lower in old subjects with atrophy. Acid output ( $\mathrm{mmol} / \mathrm{h}$ ) in subjects with atrophy was lower than in subjects with no atrophy (basal: $3.0(1.1) ; 5 \cdot 1(0.7) ; p=N S$; sham fed: 5.4 (1.4); 9.3 (0.8); p<0.02; maximal: 18.9 (4.0); $31.4(1.8)$; $<0.002$; peak: $25 \cdot 1$ (5.3); $43.4(2.7)$; $\mathbf{p}<0.003)$. However, acid secretion in old subjects without atrophy was not different to that in young subjects, irrespective of $H$ pylori status. These results did not differ when acid output was expressed as $\mathrm{mmol} / \mathrm{h} / \mathrm{kg}$ lean body mass or $\mathrm{mmol} / \mathrm{h} / \mathrm{kg}$ fat free body weight. Using multiple linear regression analysis, gastritis with atrophy was the only factor that had an independent negative effect on acid secretion. In healthy men without atrophy, gastric acid secretion is preserved with ageing and is independent of $\boldsymbol{H}$ pylori status. Atrophy, which is closely related to $H$ pylori infection, is associated with a decline in acid secretion. Increased basal serum gastrin is related to both atrophy and $H$ pylori infection but not to ageing per se.

(Gut 1993; 34: 1032-1037)
Declining gastric acid secretion has been considered a consequence of ageing but this view is being reconsidered as the importance of Helicobacter pylori infection to gastroduodenal function is recognised. Early studies predated recognition of $H$ pylori and did not define the contribution of age per se. ${ }^{1-7}$ Moreover, much of the work was methodologically flawed by small numbers of subjects, many of whom were hospital patients rather than healthy volunteers. Proximal migration of the fundic-pyloric junction has been documented with ageing, associated with an increase in the prevalence of chronic gastritis and gastric atrophy. ${ }^{8}$ The relationship between $H$ pylori, age, and gastric acid secretion is important as $H$ pylori infection causes active chronic gastritis which may progress to gastric atrophy. ${ }^{910}$ However, an age dependent reduction in secretory volume and gastric acid concentration in the presence of histologically normal mucosa has also been reported, 112 suggesting that a reduction in acid secretion with age may result from attenuation of secretory pathways or from end organ resistance to physiological stimuli.

$H$ pylori has variable effects on serum gastrin concentrations and gastric acid secretion. A raised basal and exaggerated meal stimulated gastrin response have been noted in infected duodenal ulcer patients and it has been suggested that hypergastrinaemia is one mechanism whereby $H$ pylori contributes to the ulcer diathesis. ${ }^{1314}$ Serum gastrin concentrations may also rise with age, probably because of the increased prevalence of gastric atrophy with consequent loss of acid mediated inhibition of gastrin release. $H$ pylori may cause transient hypochlorrhydria in acutely infected subjects ${ }^{15} 16$ but normal levels of gastric acidity have been observed in asymptomatic, presumably chronically infected subjects. ${ }^{17}$ The long term sequelae of infection on acid secretion have not been well defined but epidemiological evidence suggests that longstanding $H$ pylor infection may result in a reduction of acid secretion through the development of atrophic changes in the gastric mucosa. ${ }^{910}$

Recent studies have examined separately the influence of $H$ pylori and age on both gastric function and histology but the complex interrelationship between $H$ pylori infection, gastric morphology, gastric secretory function, and ageing have not been well defined. In particular, there are no data in subjects greater than 60 years of age. This study aimed to determine the effect of age on basal serum gastrin concentration, gastric secretory volumes, and acid secretion in 
healthy, asymptomatic men and to evaluate the role of $H$ pylori infection and gastric atrophy on these parameters.

\section{Methods}

Approval for the study was obtained from the Ethical Review Board of Concord Hospital. All subjects gave informed written consent before the study.

\section{SUBJECT ENROLMENT}

Volunteers were enrolled over a nine month period. The study was confined to white men. Young adult subjects were recruited from advertisements placed around the hospital and also by word of mouth. Young adulthood was defined as between 18 and 30 years of age. Old subjects were recruited from local senior citizens' social clubs and defined as those greater than 65 years of age. Before entry to the study, volunteers underwent a thorough medical interview and physical examination. For inclusion in the study subjects had to be considered healthy and asymptomatic with no major medical illnesses and in particular, no past or present history of gastroduodenal disease or dyspeptic symptoms. Subjects who had recently taken antibiotics or ulcer medication, including antacids, were excluded. Seven subjects smoked (six old, one young), but no subject drank alcohol to excess.

\section{STUDY PROTOCOL}

Serum gastrin and gastric acid secretion studies All studies were performed in the morning after an overnight fast. A venous blood sample was taken for blood typing, parietal cell and intrinsic factor antibodies, and for determination of basal serum gastrin concentration, which was measured by radioimmunoassay. After this a $16 \mathrm{~F}$ nasogastric tube was inserted and the overnight secretions were aspirated. Adequacy of tube placement was determined by obtaining $<90 \%$ return of a $50 \mathrm{ml}$ aliquot of instilled water. The stomach was aspirated for 10 minutes before the start of the study. Gastric secretions were then aspirated continuously using a suction pump, with suction applied for 50 out of each 60 seconds and secretions collected in 15 minute aliquots. Secretions were obtained for 60 minutes for estimation of basal acid output. After this, subjects were sham fed a standard test meal for determination of sham fed acid output, as previously described. ${ }^{18}$ Sham fed acid output was measured for 60 minutes ( 30 minutes during and 30 minutes after feeding). After this, pentagastrin $(6 \mu \mathrm{g} / \mathrm{kg})$ was administered subcutaneously and gastric juice was collected for a further 60 minutes for estimation of maximal and peak acid output. Gastric secretory volume was measured in each phase. The hydrogen ion concentration was measured by the glass electrode method ${ }^{19}$ with an Orion autotitrator. Acid output was calculated by multiplying the hydrogen ion concentration by the volume of the gastric aspirate. Gastric acid secretion was expressed as $\mathrm{mmol} / \mathrm{h}, \mathrm{mmol} / \mathrm{h} / \mathrm{kg}$ lean body mass, and $\mathrm{mmol} / \mathrm{h} / \mathrm{kg}$ fat free body weight according to formulae previously described. ${ }^{20-22}$ Basal, sham fed, and maximal acid output were defined as the sum of the four 15 minute outputs in each period. Peak acid output was defined as the two highest consecutive 15 minute outputs after pentagastrin, multiplied by two to express the results as $\mathrm{mmol} / \mathrm{h}$.

\section{Endoscopy}

On a separate morning, within one week of the acid secretion studies, each subject underwent oesophagogastroduodenoscopy. Six mucosal biopsy specimens were taken from the antrum and four from both the corpus and fundus of the stomach.

\section{HISTOLOGICAL ASSESSMENT}

Biopsy specimens were examined with haematoxylin and eosin and modified Giemsa stains by a single histopathologist who was unaware of the age, acid secretion, or urease test results of each subject. Gastritis, including the presence and severity of gastric atrophy, was assessed using the Sydney system classification ${ }^{23}$ and the presence of $H$ pylori was also recorded.

\section{DETECTION OF H PYLORI}

One biopsy specimen from the antrum and another from the corpus were used for rapid urease testing (CLO test, Delta West). Another of the antral biopsy specimens was Gram stained and cultured. The remaining specimens were examined histologically. A subject was considered $H$ pylori positive if the organism was detected by any test from any region of the stomach.

\section{STATISTICAL ANALYSIS}

Results for each continuous variable are expressed as mean (SEM). Fisher's exact test was used to determine the differences in proportions of $H$ pylori positive and negative subjects with and without atrophy in old subjects. Differences between subgroups of subjects for each continuous variable were compared using two tailed Student's $t$ tests and analysis of variance where appropriate. Pearsons correlation coefficient was calculated to measure the association between continuous variables. These analyses were done using several variables, including age (young or old), height, weight, lean body mass, fat free body weight, blood type, $H$ pylori status, and presence of atrophy to determine the relation-

TABLE I Comparison of anthropometric measures between young and old subjects (mean (SEM))

\begin{tabular}{lccc}
\hline Measure & Young men & Old men & $p$ \\
\hline No & 22 & 28 & \\
Age $(y)$ & $22.9(0 \cdot 6)$ & $72.9(1 \cdot 2)$ & \\
Height $(\mathrm{m})$ & $181 \cdot 2(1 \cdot 2)$ & $171 \cdot 6(1 \cdot 2)$ & $<0.001$ \\
Weight $(\mathrm{kg})$ & $74.6(1 \cdot 8)$ & $77 \cdot 1(2 \cdot 2)$ & $\mathrm{NS}$ \\
Lean body mass $(\mathrm{kg})$ & $56 \cdot 4(0 \cdot 9)$ & $53.9(1 \cdot 0)$ & $\mathrm{NS}$ \\
Far free body weight $(\mathrm{kg})$ & $48 \cdot 3(0 \cdot 7)$ & $42 \cdot 7(0 \cdot 7)$ & $<0.001$ \\
\hline
\end{tabular}




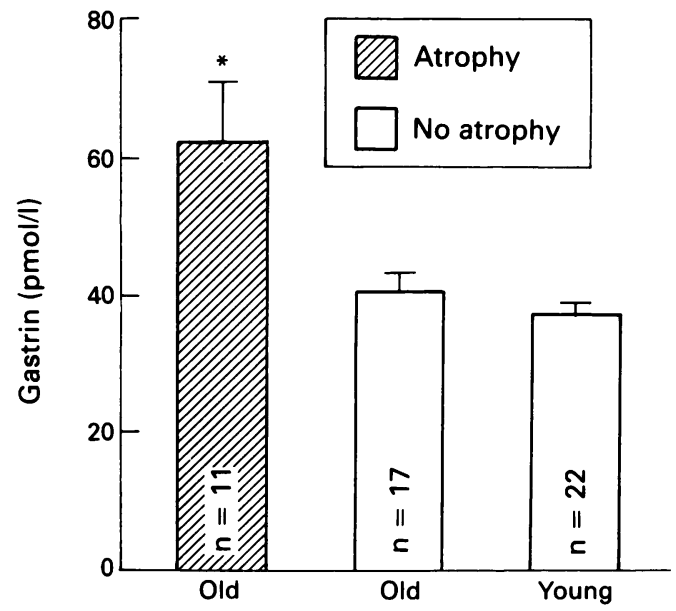

Figure 1: The effect of atrophy on basal serum gastrin concentrations in old and young subjects. ${ }^{\star}$ ANOVA $p<0.001$

ship of each to subgroups of subjects, serum gastrin concentrations, and acid secretion. Variables that showed any significant differences $(p<0.05)$ were entered into a stepwise multiple linear regression analysis. For basal serum gastrin as the dependent variable, three variables - age, $H$ pylori status, and atrophy - were considered. For gastric acid secretion, basal serum gastrin was considered in addition to these three variables.

\section{Results \\ SUBJECTS}

There was a mean of 50 years age difference between the 22 young subjects and the 28 old subjects studied. Young subjects were taller and had greater fat free body weight than old subjects but the two groups did not differ in total body weight or lean body mass (Table I).

\section{H PYLORI AND GASTRIC HISTOLOGY}

$H$ pylori infection was present in three of 22 $(13 \cdot 6 \%)$ young subjects and 16 of $28(57 \cdot 1 \%)$ old subjects. All infected subjects had active chronic gastritis on histological examination. Gastritis with atrophy was present in 11 old subjects. Atrophy of mild to moderate severity was present in the antrum, corpus, and fundus in eight of 11 subjects and in the antrum only in the remaining three. Analysis of acid output including or excluding these three subjects did not significantly alter the results. Parietal cell and intrinsic factor blocking antibodies were not detected in any subject with atrophy. The presence of atrophy was strongly associated with $H$ pylori infection: 10 of 11 old subjects with atrophy were $H$ pylori positive whereas only one

TABLE II Results of multiple linear regression analysis to predict acid secretion and serum gastrin concentrations in 50 healthy subjects

\begin{tabular}{llllll}
\hline Parameter & Predictive variable & $T=$ & Association & $\begin{array}{l}\text { Estimate } \\
\text { of } \text { effect }\end{array}$ & $p$ \\
\hline Sham fed acid output & Gastritis with atrophy & $-2 \cdot 50$ & Negative & $-3 \cdot 8(1.5)$ & $<0.02$ \\
Maximal acid output & Gastritis with atrophy & $-3 \cdot 14$ & Negative & $-12 \cdot 3(3.9)$ & $<0.01$ \\
Peak acid output & Gastritis with atrophy & $-3 \cdot 10$ & Negative & $-18 \cdot 1(5 \cdot 8)$ & $<0.01$ \\
Gastrin & Gastritis with atrophy & 3.96 & Positive & $+23.4(5.9)$ & $<0.001$ \\
\hline
\end{tabular}

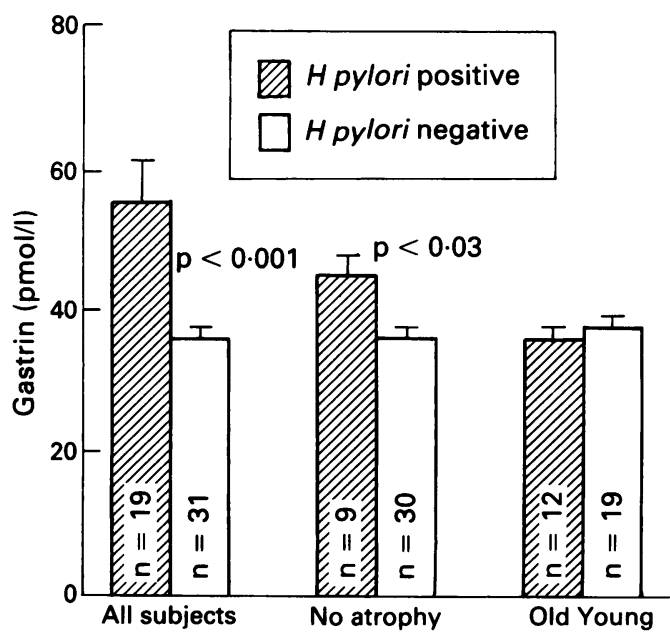

Figure 2: The effect of Helicobacter pylori infection on basal serum gastrin concentrations in all subjects and in those without atrophy.

of 12 who were $H$ pylori negative had atrophy $(p<0.005)$. No young subject had evidence of atrophic changes. Smokers were distributed randomly among subgroups.

\section{BASAL SERUM GASTRIN CONCENTRATIONS}

Mean basal serum gastrin concentrations were significantly higher in old subjects than young subjects overall $(48.8(4.4) v 36.8(2.3) \mathrm{pmol} / \mathrm{l}$ respectively, $\mathrm{p}<0 \cdot 03)$. Subjects with atrophy had significantly higher serum gastrin concentrations than all other subjects and higher than old subjects without atrophy. In old subjects without atrophy, serum gastrin values were not different to those in young subjects (Fig 1). $H$ pylori infected subjects (young and old) had higher serum gastrin concentrations on average than uninfected subjects. This was still the case when subjects with atrophy were excluded from this analysis. In $H$ pylori negative subjects, however, serum gastrin concentrations did not vary with age (Fig 2). Using multiple linear regression, atrophy had an independent positive effect on basal serum gastrin concentrations whereas age did not (Table II).

\section{GASTRIC SECRETORY VOLUMES}

Mean basal secretory volume was less in old subjects overall $(71(7) \mathrm{ml} ; \mathrm{p}<0.01)$, and in old subjects without atrophy $(66(8) \mathrm{ml} ; \mathrm{p}<0.02)$ than in young subjects (110 (14) $\mathrm{ml})$. Subjects with atrophy had lower maximal secretory volumes than those without atrophy $(188(26) \mathrm{ml}$ $v 261$ (15) $\mathrm{ml}$ respectively; $\mathrm{p}<0.02$ ), while maximal volumes were not different between old subjects with normal histology and young subjects. $H$ pylori infection did not appear to affect secretory volumes (data not shown).

\section{GASTRIC ACID SECRETION}

Subjects with atrophy had lower mean sham fed, maximal, and peak acid output than all other subjects (Fig 3). This was also true when only old subjects with and without atrophy were compared: sham fed acid output: $5 \cdot 4(1 \cdot 4) ; 9 \cdot 4(1 \cdot 2)$; 
TABLE III Comparison of total and adjusted acid secretion in old and young subjects without atrophy and in subjects with neither atrophy nor Helicobacter pylori infection

\begin{tabular}{|c|c|c|c|c|c|c|c|c|}
\hline & \multicolumn{2}{|c|}{ Basal acid output ${ }^{\star}$} & \multicolumn{2}{|c|}{ Sham fed acid output ${ }^{\star}$} & \multicolumn{2}{|c|}{ Maximal acid output ${ }^{\star}$} & \multicolumn{2}{|c|}{ Peak acid output ${ }^{\star}$} \\
\hline & Old & Young & Old & Young & Old & Young & Old & Young \\
\hline $\begin{array}{l}\text { No atrophy\#: } \\
\mathrm{mmol} / \mathrm{h} \\
\mathrm{mmol} / \mathrm{h} / \mathrm{kg} \text { lean body mass } \\
\mathrm{mmol} / \mathrm{h} / \mathrm{kg} \text { fat free body weight } \\
\text { No } H \text { pylori or atrophyt: }\end{array}$ & $\begin{array}{l}5.08(0.69) \\
0.09(0.01) \\
0 \cdot 12(0.01)\end{array}$ & $\begin{array}{l}5 \cdot 18(1 \cdot 21) \\
0.09(0.02) \\
0 \cdot 11(0.03)\end{array}$ & $\begin{array}{l}9 \cdot 34(1 \cdot 2) \\
0 \cdot 17(0.02) \\
0 \cdot 21(0.03)\end{array}$ & $\begin{array}{l}9 \cdot 28(0.97) \\
0 \cdot 17(0.02) \\
0.19(0.02)\end{array}$ & $\begin{array}{r}31.80(3.35) \\
0.58(0.06) \\
0.72(0.08)\end{array}$ & $\begin{array}{r}31 \cdot 11(1.79) \\
0.55(0.03) \\
0.65(0.04)\end{array}$ & $\begin{array}{r}44 \cdot 12(5 \cdot 00) \\
0 \cdot 80(0 \cdot 09) \\
1 \cdot 01(0 \cdot 11)\end{array}$ & $\begin{array}{r}42.80(3.08) \\
0.76(0.05) \\
0.89(0.06)\end{array}$ \\
\hline $\begin{array}{l}\mathrm{mmol} / \mathrm{h} \\
\mathrm{mmol} / \mathrm{h} / \mathrm{kg} \text { lean body mass } \\
\mathrm{mmol} / \mathrm{h} / \mathrm{kg} \text { fat free body weight }\end{array}$ & $\begin{array}{l}5 \cdot 18(0.91) \\
0.09(0.02) \\
0.12(0.02)\end{array}$ & $\begin{array}{l}4.51(1.03) \\
0.08(0.02) \\
0.10(0.02)\end{array}$ & $\begin{array}{l}8.65(1.65) \\
0 \cdot 16(0.03) \\
0.20(0.04)\end{array}$ & $\begin{array}{l}8.71(0.96) \\
0.15(0.02) \\
0.18(0.02)\end{array}$ & $\begin{array}{r}28.66(3.62) \\
0.52(0.06) \\
0.66(0.08)\end{array}$ & $\begin{array}{r}30.56(1.77) \\
0.55(0.03) \\
0.64(0.04)\end{array}$ & $\begin{array}{r}39.91(5.43) \\
0.73(0.09) \\
0.92(0.12)\end{array}$ & $\begin{array}{r}42.80(3.08) \\
0.76(0.05) \\
0.87(0.05)\end{array}$ \\
\hline
\end{tabular}

^No significant differences are present between young and old subjects with any method of expressing acid secretion. \#Old $n=17$, young $n=22$. + Old $n=11$, young $n=19$.

p < 0.04; maximal acid output: $18.9(4.0) ; 31.8$ (3.35); p <0.02; peak acid output: $25 \cdot 1$ (5.3); $44 \cdot 1(5 \cdot 0) ; \mathrm{p}<0.02$. There was no significan difference in acid secretion between $H$ pylori positive and negative subjects overall (not shown), or between $H$ pylori positive and negative subjects without atrophy (Fig 4). There was no age related difference in acid secretion in old men without atrophy and young men, irrespective of $H$ pylori status (Table III). Basal serum gastrin concentration was negatively associated with maximal acid output $(\mathrm{r}=-0.36 ; \mathrm{p}<0.02)$ and peak acid output $(r=-0 \cdot 34 ; p<0.02)$. Using multiple linear regression, only the presence of gastritis with atrophy was independently and negatively associated with sham fed, maximal, and peak acid output (Table II). When acid secretion was expressed corrected for lean body mass and fat free body weight these findings did not differ to those using acid output expressed as $\mathrm{mmol} / \mathrm{h}$ (Table III).

\section{Discussion}

This work shows that gastric acid secretion does not decline as a result of healthy ageing, but rather as a consequence of the development of atrophic changes of the gastric mucosa. The belief that acid secretion declines with advancing age has been widespread. Early studies supporting this concept were done using suboptimal

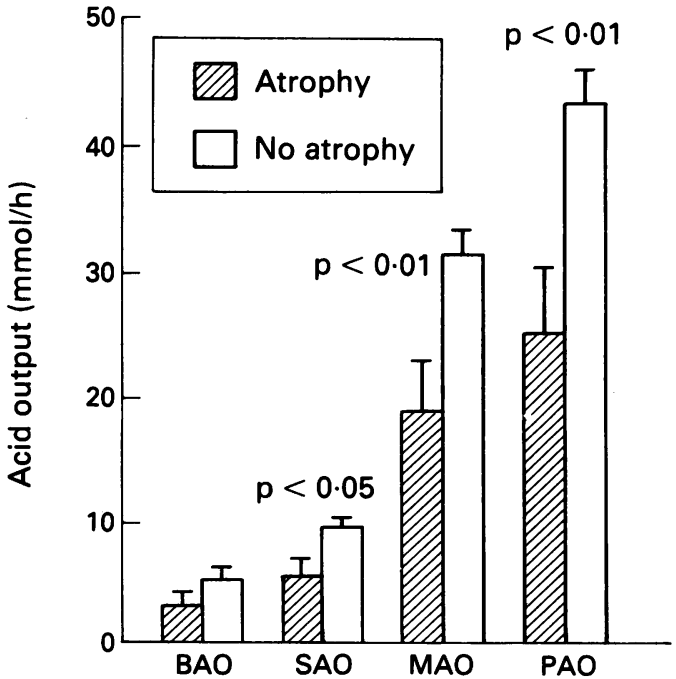

Figure 3: The effect of atrophy on basal, sham fed, and pentagastrin stimulated gastric acid secretion in asymptomatic subjects (atrophy $n=11$, no atrophy $n=39$ ). $B A O=$ basal acid output, $S A O=$ sham fed acid output, $M A O=$ maximal acid output, $P A O=$ peak acid output. techniques on small numbers of subjects, most of whom were hospital inpatients or outpatients with a variety of medical conditions, rather than healthy asymptomatic subjects. These studies preceded the recognition of $H$ pylori and its role in gastroduodenal disorders, and most did not consider the effect of the histological condition of the gastric mucosa on gastric function. ${ }^{1-7}$ Furthermore, the findings conflicted in that some studies did not show an age related decline in acid secretion. ${ }^{672425}$ More recently, a decrease in pentagastrin stimulated acid output in older subjects was associated with an increasing incidence and severity of atrophic changes to the body mucosa with advancing age..$^{22}$ However, a decline in pentagastrin stimulated gastric acid secretion with age was seen in those subjects with superficial gastritis also. In another recent study, age was reported to have an independent positive effect on gastric acid secretion while $H$ pylori infection (measured by ELISA) had an independent negative effect. ${ }^{26}$ The mean age difference between old and young subjects in this study, however, was 24 years compared with 50 years in the present study. Furthermore, the state of the gastric mucosa was not described. The prevalence of active chronic gastritis and subsequent gastric atrophy increases with age. It is known that this is almost exclusively the result of the age

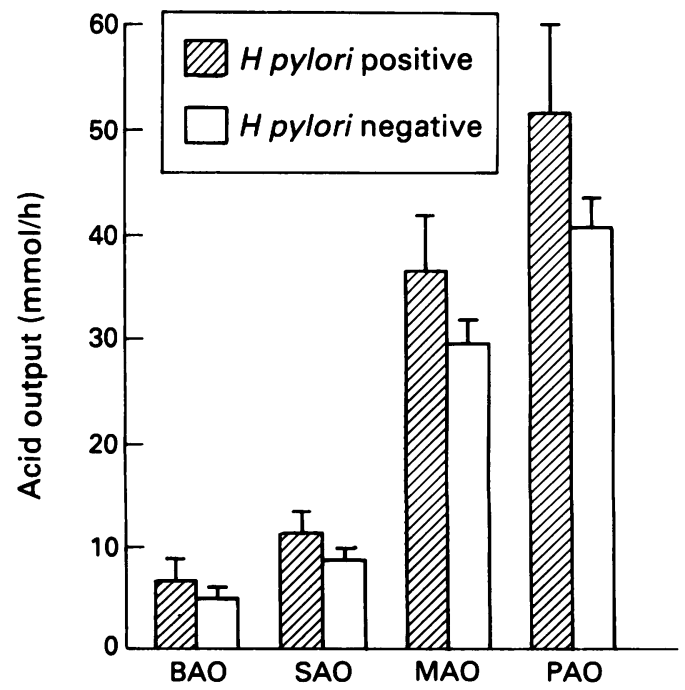

Figure 4: The effect of Helicobacter pylori infection on gastric acid secretion in subjects without atrophy. Basal, sham fed, and pentagastrin stimulated acid secretion were not significantly different between $\mathrm{H}$ pylori positive $(n=9)$ and $\mathrm{H}$ pylori negative subjects $(n=30) . B A O=$ basal acid output, $S A O=$ sham fed acid output, $M A O=$ maximal acid output, $P A O=$ peak acid output. 
related increase in the prevalence of $H$ pylori infection. As virtually all $H$ pylori infected subjects have active chronic gastritis which precedes the development of atrophic changes, it is not possible to assess the direct effect of $H$ pylori infection on acid secretion from that study without knowing which subjects had developed atrophy. In this study $H$ pylori infection was present in all old subjects with atrophy with one exception. The exception is not remarkable as $H$ pylori has been reported to disappear from the stomachs of subjects in whom atrophy, with consequent hypochlorrhydria, has supervened as the organism requires acid secreting mucosa to survive. ${ }^{27}$

An age dependent decline in acid output and gastric secretory volume has been reported in old subjects with normal gastric mucosa. ${ }^{112}$ If this were true, it would suggest an attenuation of neural pathways mediating acid secretion or end organ (parietal cell) resistance to stimulation. We have not found a diminution in gastric acid output in old subjects with histologically normal stomachs under basal or stimulated conditions. Acid output and secretory volumes were preserved during sham feeding, which is considered to assess cholinergic (vagal) pathways ${ }^{1828}$ and after gastrinergic stimulation with pentagastrin. Thus, in health, there does not seem to be either an attenuation of secretory pathways mediating gastric acid secretion or end organ resistance to stimulation.

Expressing acid secretion corrected for lean body mass is considered to avoid bias caused by variation in parietal cell mass due to differences in the gastric surface area, as this accounts for differences in height and weight. ${ }^{22} \mathrm{~A}$ change in body weight with ageing may be partly the result of an increment in fat mass. Expressing acid secretion corrected for fat free body weight will take this into account. In this study, fat free body weight (but not lean body mass) was lower in old subjects, but the comparison of acid secretion between the two groups did not change when the data were analysed corrected for fat free body weight or lean body mass.

Serum gastrin concentrations have been reported to rise with age. ${ }^{10}$ On the basis of the present study, this seems to be caused by two factors. Gastritis with atrophy and the consequent loss of acid mediated inhibition of gastrin release contributes most to this increase. Basal serum gastrin, however, was also high in $H$ pylori infected subjects without atrophy, supporting the concept of an independent stimulatory effect of the organism of gastrin release. The interactions of $H$ pylori with gastrin release and gastric acid secretion are complex and seem to depend, in part, on the duration of infection. Transient hypochlorrhydria because of $H$ pylori in acutely infected subjects has been noted in studies that included healthy volunteers..$^{15} 16$ Raised basal gastrin and exaggerated meal stimulated gastrin responses have been described in infected duodenal ulcer patients. ${ }^{134}$ This hypergastrinaemia may account for the increased acid secretion seen in some duodenal ulcer patients and may be one mechanism whereby $H$ pylori contributes to the ulcer diathesis. Normal levels of 24 hour intragastric acidity have been observed in asympto- matic, presumably chronically infected, subjects, ${ }^{17}$ and acid secretion was not raised in $H$ pylori positive subjects in the present study. Subjects will have been infected for varying lengths of time, which may affect these findings. The long term sequelae of infection on acid secretion are not well defined but longstanding, $H$ pylori associated chronic active gastritis does result in atrophy which in turn results in a reduction in acid secretion..$^{9}$

In summary, the prevalence of both $H$ pylori infection and gastritis with atrophy increase with age but in healthy men without these pathological conditions, gastric acid secretion does not decline with ageing. Diminished gastric acid secretion is related to the presence of atrophy. Similarly, basal serum gastrin concentrations do not alter with ageing in healthy men. Increased basal serum gastrin is related to atrophy and to infection with $H$ pylori.

Dr Katelaris was supported by a University of Sydney Medical Research Fellowship. This project was supported by a grant from the Central Health and Medical Research Council. The authors thank Jane Abraham RN and the endoscopy staff for their excellent technical assistance and Ms Janice Thomas for valuable help with statistics and the Microbiology Dept for the $H$ pylori cultures.

Parts of this work were presented in abstract form at the British Society of Gastroenterology Meeting, University of Warwick, September 1992 and at the V European Workshop on GastroDublin, July, 1992.

1 Baron JH. Studies of basal and peak acid output with an augmented histamine test. Gut 1963; 4: 136-44

2 Blackman AH, Lambert DL, Thayer WR, Martin HF Computed normal values for peak acid output based on age,

3 Grossman MI, Kirsner JB, Gillepsie IE. Basal and histalogstimulated gastric secretion in control subjects and in stimulated gastric secretion in control subjects and in
patients with peptic ulcer or gastric cancer. Gastroenterology
$1963 ; 45: 14-26$.

4 Levin E, Kirsner JB, Palmer WL. A simple measure of gastric secretion in man. Comparison of one hour basal secretion, histamine secretion and twelve hour nocturnal gastric secretion. Gastroenterology 1951; 19: 88-98.

5 Rohrer GV, Welsh JD. Correlative study: gastric secretion and histology. Gastroenterology 1967; 52: 185-91.

6 Wormsley KG, Grossman MI. Maximal histalog test in control subjects and patients with peptic ulcer. Gut 1965; 6: 427-35.

7 Goyal RK, Gupta PS, Chuttani HK. Gastric acid secretion in India with particular reference to the ratio of basal to maximal acid output. Gut 1966; 7: 619-23.

8 Kimura K. Chronological transition of the fundic-pyloric border determined by stepwise biopsy of the lesser and greater curvatures of the stomach. Gastroenterology 1972; 63: greater curv

9 Sipponen P, Kekki M, Siurala M. The Sydney system: epidemiology and natural history of chronic gastritis. epidemiology and natural history of chro
f Gastroenterol $\mathcal{E}$ Hepatol 1991; 6: 244-51.

10 Sipponen P. Long-term consequences of gastroduodenal inflammation. Eur f Gastroenterol Hepatol 1992; 4 (suppl 2): S25-9.

11 Krentz K, Jablonowski H. Functional and histological changes with age. In: Hellemans J, Vantrappen G, eds. Gastrointestinal tract disorders in the elderly. Edinburgh: Churchill Livingstone, 1984: 62-9.

12 Fikry ME. Gastric secretory functions in the aged. Gerontol Clin 1965; 7: 216-26.

13 Levi S, Beardshall K, Haddad G, Playford R, Ghosh P, Calam J. Campylobacter pylori and duodenal ulcer: the gastrin link. Lancet 1989 ; i: $1167-8$.
Lampylobact

14 Graham DY, Opekun A, Lew GM, Klein PD, Walsh JH. Helicobacter pylori-associated exaggerated gastrin release in duodenal ulcer patients. Gastroenterology 1991; 100: 1571-5.

15 Morris A, Nicholson G. Ingestion of Campylobacter pyloridis causes gastritis and raised fasting gastric pH. Am $\mathcal{J}$ Gastroenterol 1987; 82: 192-9.

16 Morris A, Nicholson G. Experimental and accidental $C$ pylori infection in humans. In: Blaser MJ, ed. Campylobacter pylori in gastritis and peptic ulcer disease. New York: Igaku Shoin Medical Publishers, 1989: 61-72.

17 Wagner S, Gladziwa U, Haruma K, Varrentrapp M, Gebel M. Effect of Helicobacter pylori on 24 hour intragastric acidity in patients with gastritis and duodenal ulcer. Gut 1992; 33: 1024-8.

18 Feldman M, Richardson CT, Fordtran JS. Effect of shamfeeding on gastric acid secretion in healthy subjects and duodenal ulcer patients. Evidence for increased basal vagal tone in some ulcer patients. Gastroenterology 1980; 79: 796-
800 . 9 Moore EW, Scarlata RW. The determination of gastric acidity
by the glass electrode. Gastroenterology $1965 ; 49: 178-88$. 
20 Moore FD, Olesen KH, McMurrey JD, Parker HV, Ball MR, Boyden CM, eds. The body cell mass and its supporting environment. Body composition in health and disease. Saunders: Philadelphia, 1963: 166.

21 Hume R. Prediction of lean body mass from height and weight. $\mathcal{F}$ Clin Pathol 1966; 19: 389-91.

22 Kekki M, Samloff IM, Ihamaki T, Varis K, Siurala M. Ageand sex-related behaviour of gastric acid secretion at the population level. Scand $\mathcal{F}$ Gastroemterol 1982; 17:737 43 .

23 Price AB. The Sydney system: histological division. f Gastroenterol Hepatol 1991; 6: 209-22.

24 Hobsley M, Faber RG, Whitfield PF, Parkin JV. Hypersecretion and length of history in duodenal ulceration. Lancet 1975; 2: 101-4.
25 Cleator IGM, Stoller JL, Nunn PN, Holubitsky IB, Johnstone FRC, Harrison RC. Discriminant analysis of data in ulcer and non-ulcer populations. Dig Dis 1973; 18: 301-10.

26 Goldschmiedt M, Barnett CC, Schwarz BE, Karnes WE Redfern JS, Feldman M. Effect of age on gastric acid secretion and serum gastrin concentrations in healthy men and women. Gastroenterology 1991; 101: 977-90.

27 Karnes WE Jr, Samloff IM, Siurala M, Kekki M, Sipponen P Kim SWR, et al. Positive serum antibody and negative tissue staining for Helicobacter pylori in subjects with atrophic body
gastritis. Gastroenterology 1991; 101: 167-74. 28 Merki HS, Wilder-Smith CH, Walt RP, Halter F. The cephalic phase of gastric secretion during $\mathrm{H}_{2}$-antagonist treatment. Gastroenterology 1991; 101: 599-606. 